\title{
Perbedaan Hasil Belajar Matematika Menggunakan Model Pembelajaran SAVI (Somatic, Auditory, Visual, Intellectuall) Dengan Pendekatan Saintifik Pada Siswa Kelas VIII SMP N 4 Kota Bengkulu
}

\author{
Rafi Putra', Della Maulidiya, S.Si, M.Kom. ${ }^{2}$, dan Effie Efrida Muchlis, S.Pd., M.Pd. ${ }^{3}$ \\ ${ }^{1,2,3}$ Program Studi Pendidikan Matematika, FKIP Universitas Bengkulu \\ Email:1'nanibruno42@gmail.com, 2della.maulidiya@unib.ac.id, ${ }^{3}$ effieefrida@gmail.com
}

\begin{abstract}
Abstrak
Penelitian ini bertujuan untuk mengetahui perbedaan model pembelajaran SAVI dengan saintifik pada materi Statistika terhadap hasil belajar matematika siswa kelas VIII SMPN 4 Kota Bengkulu. Jenis penelitian yang dilakukan adalah penelitian eksperimen semu dengan desain penelitian The Nonequivalent Posttest-Only Control Group Design. Populasi dalam penelitian ini yaitu siswa kelas VIII SMPN 4 Kota Bengkulu. Pemilihan sampel dilakukan dengan teknik Purposive Sampling ditentukan berdasarkan nilai rata-rata tes awal siswa yang sama. Sehingga diperoleh siswa kelas VIII 7 berjumlah 35 orang sebagai kelas eksperimen dan kelas VIII 6 yang terdiri dari 36 orang siswa sebagai kelas kontrol. Uji prasyarat analisis dengan menggunakan uji normalitas dan uji homogenitas. Analisis data dilakukan dengan uji-t independent, diperoleh bahwa uji-t independent untuk hasil postes kedua kelas sampel dengan taraf signifikan $(\alpha=0,05)$ didapat angka sig.(2-tailed) $=0,000<$ taraf signifikan $(\alpha=0,05)$ dan $t_{\text {hitung }}=4,061>t_{\text {tabel }}=1,994$ maka $\mathrm{H}_{0}$ ditolak. Menunjukkan bahwa terdapat perbedaan hasil belajar matematika antara siswa yang menggunakan model pembelajaran SAVI dengan pendekatan saintifik dan siswa yang menggunakan pendekatan saintifik saja pada kelas VIII SMP Negeri 4 Kota Bengkulu.
\end{abstract}

Kata Kunci : Hasil belajar, Model pembelajaran SAVI (Somatic, Auditori, Visual, Intellectuall)

\begin{abstract}
The aim of this study to know SAVI difference with scientific learning model at Statistics material to the results of students' mathematics learning class VIII SMPN 4 Kota Bengkulu. Type of research is quasi-experimental research design with research The Nonequivalent Posttest-Only Control Group Design. The population in this research is class VIII SMPN 4 Kota Bengkulu. Sample selection is done by purposive sampling technique is determined based on the average value of the initial tests the same students. Thus obtained the eighth grade 7 totaling 35 people as an experimental class and class VIII 6 which consists of 36 students as control class. Prerequisite test analysis using normality test and homogeneity test. Data were analyzed by independent t-test, found that the independent $t$-test to the results of the second post-test sample classwith a significant level obtained $(\alpha=0,05)$ gained sig rate. $(2$-tailed $)=0,000<$ significant level $(\alpha=0,05)$ and $t_{\text {count }}=4,061>t_{\text {table }}=1,994$ then $\mathrm{H}_{0}$ is rejected. It indicates that there are differences in learning outcomes mathematics between students who use learning model SAVI approach to scientific and students who use the approach of scientific course at class VIII SMPN 4 Kota Bengkulu
\end{abstract}

Keywords: learning outcomes, SAVI learning model (Somatic, Auditori, Visual, Intellectuall)

\section{PENDAHULUAN}

Mengingat pentingnya matematika, maka matematika menjadi suatu yang wajib diajarkan kepada siswa disetiap jenjang pendidikan, dimulai dari taman kanak-kanak, sekolah dasar, sekolah menengah pertama, sekolah menengah atas, hingga tingkat perguruan tinggi. Mengajarkan dan menanamkan arti pentingnya matematika tidaklah mudah, perlu usaha ekstra dan kerja keras. Hal ini dikarenakan, sampai 
saat ini pemikiran bahwa matematika itu sulit dan rumit, matematika adalah ilmu pengetahuan yang kering, abstrak, teoritis, penuh dengan lambang-lambang dan rumusrumus yang sulit (Yumiati, 2009: 2). Hal ini tentu menjadi kerugian bagi semua pihak, terutama siswa itu sendiri yang dapat menurunkan hasil belajar siswa. Ini menjadi permasalahan sangat serius yang harus dicarikan solusinya.

Penulis melakukan wawancara pada hari Jum'at tanggal 26 Januari 2018 dengan seorang guru matematika di SMPN 4 Kota Bengkulu yang sudah menerapkan kurikulum 2013 yakni Bapak Mukhtarimin. Hasil wawancara tersebut menjelaskan tentang proses pembelajaran peserta didik yang sudah menerapkan pembelajaran pendekatan saintifik. Namun menurut pak Mukhtarimin siswa masih kurang aktif bertanya dan hanya mengandalkan pengetahuan yang diberikan oleh guru tersebut. Siswa tidak aktif dalam menggunakan buku pelajaran (buku paket) yang telah dipinjamkan oleh sekolah. Sehingga ketika menyelesaikan masalah dalam pelajaran matematika siswa masih perlu bimbingan yang lebih dari guru.

Solusi dalam mengatasi masalah pada pembelajaran matematika dan agar tujuan pembelajaran matematika tercapai, maka perlu melakukan perubahan dalam pembelajaran matematika, dari pembelajaran yang berorientasi pada guru menjadi pembelajaran yang berorientasi pada siswa. Salah satu alternatif yang dapat ditempuh untuk meningkatkan hasil belajar matematika siswa SMPN 4 Kota Bengkulu adalah dengan cara menciptakan pembelajaran yang pengetahuannya diperoleh dari siswa itu sendiri.

Salah satu model pembelajaran yang menekankan pada pengetahuan siswa adalah model SAVI (Somatic, Auditory, Visualization, Intellectuall). Meier dalam Huda (2014: 283) mengatakan pembelajaran SAVI merupakan inti dari Accelerated Learning (AL) atau pembelajaran yang dipercepat. Model pembelajaran SAVI (Somatis, Auditori, Visual,
Intellectuall) adalah pembelajaran yang menekankan bahwa belajar haruslah memanfaatkan semua alat indra yang dimiliki peserta didik (Suyatno, 2009 : 65). Meier dalam Rusman (2011: 373) mengemukakan bahwa pembelajaran SAVI adalah pembelajaran yang melibatkan kelima indera dan emosi dalam proses belajar. Sedangkan Shoimin (2014 : 177) berpendapat bahwa pembelajaran SAVI adalah pembelajaran yang memanfaatkan semua alat indera yang dimiliki siswa.

Pendekatan saintifik ialah pendekatan yang digunakan dalam pembelajaran melalui proses pengamatan (observasi), mengajukan pertanyaan, mengumpulkan informasi, menalar, dan komunikasi. Proses-proses tersebut harus di implementasikan pada saat memasuki kegiatan pembelajaran. Proses mengamati peserta didik akan dilatih menggunakan panca indra untuk mengeksplorasi rasa keingin tahuannya tentang objek pembelajaran agar dapat memperoleh informasi. Proses mengajukan pertanyaan siswa dilatih untuk merumuskan pertanyaan berdasarkan topik yang akan dipelajari. Aktivitas pembelajaran ini penting untuk meningkatkan keingintahuan dalam diri peserta didik. Proses mencoba dan mengumpulkan data bertujuan agar peserta didik terlatih mengembangkan ketelitian dan mengumpulkan data dari berbagai sumber. Proses mengasosiasikan akan mengembangkan kemampuan mengolah informasi melalui penalaran dan berpikir rasional. Proses komunikasi kemampuan untuk membangun jaringan dan berkomunikasi sangat perlu dimiliki oleh peserta didik karena kompetensi tersebut sama pentingnya dengan pengetahuan, keterampilan, dan pengalaman.

Semua proses tersebut merujuk pada kriteria mengenai kualifikasi kemampuan yang mencakup sikap, pengetahuan dan keterampilan yang ada pada kurikulum 2013. Penerapan pendekatan saintifik dapat membentuk siswa yang kreatif, mandiri, serta memiliki ilmu yang dapat dimanfaatkan untuk perkembangan kemampuannya. 
Uraian di atas, mendorong peneliti untuk meneliti apakah ada pengaruh model pembelajaran SAVI dengan pendekatan saintifik terhadap hasil belajar siswa, agar tercapainya pembelajaran matematika yang berpusat pada siswa dan memposisikan guru sebagai fasilitator. Perbedaan hasil belajar antara kelas yang menerima model pembelajaran SAVI dengan pendekatan saintifik dengan kelas hanya pendekatn saintifik saja. Hal ini diharapkan mampu mengubah siswa yang awalnya kurang aktif menjadi lebih aktif dalam pembelajaran matematika. Dengan demikian perlu dilakukan penelitian dengan judul "Perbedaan Hasil Belajar Matematika Menggunakan Model Pembelajaran SAVI dengan Pendekatan Saintifik dan Hasil Belajar dengan Pendekatan Saintifik Pada Siswa Kelas VIII SMPN 4 Kota Bengkulu."

\section{METODE PENELITIAN}

Jenis penelitian yang digunakan dalam penelitian ini merupakan eksperimen semu (Quasy Experiment). Pada kelas sampel pertama (kelas eksperimen) dilaksanakan pembelajaran dengan model pembelajaran SAVI dengan pendekatan saintifik dan pada kelas sampel kedua (kelas kontrol) dilaksanakan pembelajaran dengan pendekatan saintifik. Penelitian ini dilakukan di SMP Negeri 4 Kota Bengkulu. Populasi dalam penelitian ini adalah peserta didik Kelas VIII SMP Negeri 4 Kota Bengkulu. Pengambilan sampel dilakukan dengan menggunakan teknik purposive sampling, penentuan sampel diambil dengan pertimbangan tertentu, yaitu berdasarkan nilai rata-rata siswa yang sama.

Pada penelitian ini terdapat variabel bebas dan variabel terikat. Variabel bebas adalah variabel yang mempengaruhi atau menjadi sebab perubahannya atau timbulnya variabel dependen (terikat) (Sugiyono, 2014:61). Variabel bebas disini berarti variabel yang menjadi pengaruh dalam sebuah penelitian. Variabel bebas untuk penelitian ini yaitu model pembelajaran SAVI (kelas eksperimen) dengan pendekatan saintifik (kelas kontrol), sedangkan variabel terikat dalam penelitian ini adalah hasil belajar siswa matematika siswa. Desain dalam penelitian ini menggunakan Posttest-Only Control Design, dengan desain penelitian sebagai berikut:

Tabel 1 Desain Penelitian

\begin{tabular}{|c|c|c|}
\hline Kelas & Perlakuan & Tes akhir \\
\hline Eksperimen & $\mathrm{X}$ & $\mathrm{Y}$ \\
\hline Kontrol & $\mathrm{O}$ & $\mathrm{Y}$ \\
\hline
\end{tabular}

Sumber: modifikasi (Lestari \& Yudhanegara, 2017: 136)

Instrumen dalam penelitian ini adalah tes hasil belajar. Tes hasil belajar yang diberikan adalah tes akhir berupa soal essay yang disusun berdasarkan indikator yang sesuai dengan materi yang dipelajari, yaitu Statistika. Soal tes hasil belajar divalidasi terlebih dahulu oleh validator, lalu diuji cobakan pada kelas uji coba untuk melihat kevalidan soal, reliabilitas soal, daya pembeda soal, dan taraf kesukaran soal.

Uji validitas dalam penelitian ini menggunakan uji korelasi product moment, yaitu:

$$
r_{x y}=\frac{N \sum X Y-\left(\sum X\right)\left(\sum Y\right)}{\sqrt{\left\{n \sum X^{2}-\left(\sum X\right)^{2}\right\}\left\{n \sum Y^{2}-\left(\sum Y\right)^{2}\right\}}}
$$

(Arikunto, 1986: 138)

Selanjutnya suatu tes dapat dikatakan mempunyai taraf kepercayaan yang tinggi jika tes tersebut memberikan hasil yang tetap (Arikunto, 1986:142). Uji Realibilitas dilakukan untuk mengetahui sejauh mana hasil pengukuran tetap konsisten. Uji reliabilitas dalam penelitian ini menggunakan teknik Alpha Cronbach, dengan rumus:

$$
r_{11}=\left(\frac{n}{n-1}\right)\left(1-\frac{\sum s_{i}^{2}}{s_{t}{ }^{2}}\right)
$$

(Lestari \& Yudhanegara, 2017:

Suatu butir soal mempunyai daya pembeda yang baik apabila kelompok siswa berkemampuan tinggi menjawab benar butir soal lebih banyak dari pada kelompok siswa 
berkemampuan rendah. Untuk mengetahui hal tesebut digunakan rumus indeks daya pembeda sebagai berikut:

$$
\mathrm{DP}=\frac{\overline{\mathrm{X}}_{\mathrm{A}}-\overline{\mathrm{X}}_{\mathrm{B}}}{\mathrm{SMI}}
$$

(Lestari dan Yudhanegara, 2017: 217)

Suatu butir soal mempunyai tingakr kesukaran soal yang baik apabila butir soal tersebut tidak terlalu sulit dan tidak terlalu susah untuk diselesaikan. Untuk mengetahui tingkat kesukaran tiap butir soal digunakan rumus sebagai berikut:

$$
\mathrm{TK}=\frac{\overline{\mathrm{X}}}{\mathrm{SMI}}
$$

(Lestari dan Yudhanegara, 2015: 224)

Teknik analisa yang digunakan dalam penelitian ini adalah teknik analisa kuantitatif. Data yang diperoleh dianalisis menggunakan uji perbedaan dua rata-rata, yaitu uji normalitas, uji homogenitas dan uji hipotesis. Uji normalitas bertujuan untuk mengetahui apakah data yang dianalisis berdistribusi normal atau tidak, baik dari kelas eksperimen maupun kelas kontrol. Uji normalitas data pada penelitian ini menggunakan Chi-Kuadrat $\left(\mathcal{X}^{2}\right)$, dengan rumus:

$$
x^{2}=\sum_{i=1}^{k} \frac{\left(f_{o}-f_{h}\right)^{2}}{f_{h}}
$$

(Sugiyono, 2017: 107)

Kriteria pengujiannya adalah $\mathrm{H}_{0}$ diterima jika $\mathcal{X}_{\text {hitung }}^{2} \leq \mathcal{X}_{\text {tabel. }}^{2}$ Sebaliknya ditolak jika $\mathcal{X}_{\text {hitung }}^{2}>\mathcal{X}_{\text {tabel. }}^{2}$ Dengan taraf nyata $5 \%$ $(\propto=0,05)$.

Uji homogenitas bertujuan untuk mengetahui apakah kelas eksperimen dan kelas kontrol memiliki variansi yang tidak jauh berbeda. Jika variansi dari kedua kelas tidak jauh berbeda, maka kedua kelas dapat dikatakan homogen, sedangkan jika variansi dari kedua kelas jauh berbeda, maka dapat dikatakan tidak homogen. Uji homogenitas pada penelitian ini menggunakan uji fisher. Adapun rumusnya sebagai berikut:

$$
F=\frac{\text { Varians terbesar }}{\text { Varians terkecil }}
$$

(Sugiyono, 2017: 140)

Kriteria pengujiannya adalah $\mathrm{H}_{0}$ diterima jika $F_{\text {hitung }} \leq F_{\text {tabel }}$. Sebaliknya $\mathrm{H}_{0}$ ditolak jika $F_{\text {hitung }}>F_{\text {tabel }}$. Dengan taraf nyata $5 \%$ $(\propto=0,05)$. Jika syarat normalitas dan homogenitas terpenuhi, maka dilakukan uji hipotesis. Pengujian hipotesis menggunakan uji $\mathrm{t}$, dengan hipotesis sebagai berikut:

$\mathrm{H}_{0}$ : Tidak ada perbedaan yang signifikan antara hasil belajar matematika siswa yang menggunakan model pembelajaran SAVI dengan pendekatan saintifik dan hasil belajar matematika siswa yang menerima pendekatan saintifik.

$\mathrm{H}_{1}$ : Ada perbendaan yang signifikan antara hasil belajar matematika siswa yang menggunakan model pembelajaran SAVI dengan pendekatan saintifik dan hasil belajar matematika siswa yang menerima pendekatan saintifik.

Adapun rumus uji-t yang digunakan sebagai berikut:

$$
t=\frac{\overline{\mathrm{x}_{1}}-\overline{\mathrm{x}_{2}}}{\sqrt{\left.\frac{\left(\mathrm{n}_{1}-1\right) s_{1}{ }^{2}+\left(\mathrm{n}_{2}-1\right) s_{2}{ }^{2}}{\mathrm{n}_{1}+\mathrm{n}_{2}-2} \frac{s_{1}{ }^{2}}{\mathrm{n}_{1}}+\frac{s_{2}{ }^{2}}{\mathrm{n}_{2}}\right)}}
$$

(Lestari \& Yudhanegara, 2017: 282)

Kriteria pengujiannya adalah $\mathrm{H}_{0}$ diterima jika $t_{\text {hitung }} \leq t_{\text {tabel }\left(\alpha, n_{1}+n_{2}-2\right)}$. Sebaliknya $\mathrm{H}_{0}$ ditolak jika $t_{\text {hitung }}>t_{\text {tabel }\left(\alpha, n_{1}+n_{2}-2\right)}$. Dengan taraf nyata $5 \%(\propto=0,05)$.

\section{HASIL DAN PEMBAHASAN}

Penelitian ini dilaksanakan di SMP Negeri 4 Kota Bengkulu yang dimulai pada tanggal 2 April - 31 Mei 2018. Penelitian dilakukan untuk mengetahui apakah ada pengaruh hasil belajar matematika siswa antara model pembelajaran SAVI dengan pendekatan saintifik. Penelitian ini terdiri dari 6 pertemuan yaitu 5 pertemuan materi dan 1 pertemuan posttest. Uji coba soal posttest dilakukan pada kelas VIII 8 dengan banyak siswa 32 orang. Test yang diujikan terdiri dari 10 soal, berupa 
soal uraian dengan materi statistika. Dilakukan uji validitas dengan 2 tahap yaitu uji validitas logis dan uji validitas empiris. Setelah uji validitas dilakukan, selanjutnya dilakukan perhitungan uji reliabilitas soal, uji taraf daya pembeda soal kemudian didapatkan soal yang dianggap baik untuk di ujikan pada kelas eksperimen. Berdasarkan hasil uji coba instrumen, diperoleh hasil sebagai berikut:

Tabel 2 Hasil Perhitungan Uji Coba Instrumen

\begin{tabular}{|c|c|c|c|c|}
\hline $\begin{array}{l}\text { Butir } \\
\text { Soal }\end{array}$ & Validitas & Reliabilitas & $\begin{array}{c}\text { Tingkat } \\
\text { Kesukaran }\end{array}$ & $\begin{array}{c}\text { Daya } \\
\text { Pembeda }\end{array}$ \\
\hline 1 & Valid & \multirow{10}{*}{ Tinggi } & Sedang & Cukup \\
\hline 2 & Valid & & Sedang & Cukup \\
\hline 3 & Valid & & Sedang & Cukup \\
\hline 4 & Valid & & Sedang & Buruk \\
\hline 5 & Valid & & Sedang & Cukup \\
\hline 6 & Valid & & Sedang & Cukup \\
\hline 7 & Valid & & Sedang & Cukup \\
\hline 8 & Valid & & Mudah & Buruk \\
\hline 9 & Valid & & Sedang & Cukup \\
\hline 10 & Valid & & Sedang & Cukup \\
\hline
\end{tabular}

Berdasarkan hasil perhitungan uji validitas, reliabilitas, tingkat kesukaran dan daya pembeda, maka soal yang diujikan dan dapat dipakai untuk kelas eksperimen dan kelas kontrol sebanyak delapan soal. Delapan soal tes hasil belajar pada kelas eksperimen dengan sedikit perbaikan-perbaikan yang disarankan oleh kedua validator ahli, meliputi kalimat matematika dan bahasa yang digunakan pada soal diperjelas lagi sehingga siswa dapat dengan mudah memahami maksud yang di inginkan oleh soal tersebut. Maka.

Uji normalitas yang digunakan adalah uji Kolmoogorov_Smirnov dengan bantuan software SPSS 18, dengan hipotesis sebagai berikut:

$\mathrm{H}_{0}$ : Data berdistribusi normal

$\mathrm{H}_{1}$ : Data berdistribusi tidak normal

Kriteria pengujian yang digunakan adalah $\mathrm{H}_{0}$ diterima jika sig $>\alpha=0,05$ maka $\mathrm{H}_{0}$ diterima dan jika sig $<\alpha=0,05$ maka $\mathrm{H}_{0}$ ditolak. Berdasarkan perhitungan tersebut diperoleh hasil sebagai berikut:
Tabel 3 Hasil Uji Normalitas

\begin{tabular}{|c|c|c|c|}
\hline \multirow{2}{*}{ Kelas } & \multicolumn{3}{|c|}{ Kolmogorov-Smirnov } \\
\hline & Sig & Kriteria & Keterangan \\
\hline Eksperimen & 0,162 & 0,05 & $\begin{array}{c}\text { Data } \\
\text { Berdistribusi } \\
\text { Normal }\end{array}$ \\
\hline Kontrol & 0,192 & 0,05 & $\begin{array}{c}\text { Data } \\
\text { Berdistribusi } \\
\text { Normal }\end{array}$ \\
\hline
\end{tabular}

Berdasarkan tabel 3 dapat dilihat bahwa kelas eksperimen dan kelas kontrol memiliki data yang berdistribusi normal.

Uji homogenitas pada penelitian ini dilakukan menggunakan uji fisher. Perhitungan untuk uji homogenitas juga dilakukan dengan berbantuan software SPSS.23.0 for windows. Untuk uji homogenitas ini, data dikatakan memiliki varians yang sama atau homogen apabila nilai sig. $>$ sig. $\alpha$ yakni dengan $\alpha=0,05$. Hasil uji homogenitas data dapat dilihat pada tabel berikut:

Tabel 4 Hasil Uji Homogenitas

\begin{tabular}{|c|c|c|c|}
\hline Data & Sig. & Sig. $\boldsymbol{\alpha}$ & Keterangan \\
\hline $\begin{array}{c}\text { Kelas } \\
\text { Eksperimen }\end{array}$ & 0,079 & \multirow{2}{*}{0,05} & Homogen \\
\cline { 1 - 1 } Kelas Kontrol & 0,079 & & Homogen \\
\hline
\end{tabular}

Berdasarkan tabel 4 data membuktikan hasil tes memiliki nilai signifikan yang sama atau nilai sig. > sig. $\alpha$, maka data dikatakan homogen. Data hasil belajar yang telah memenuhi kriteria distribusi normal dan homogen, selanjutnya dilakukan uji statistik yaitu pengujian hipotesis menggunakan uji-t untuk sampel independen.

Uji hipotesis pengaruh hasil belajar kelas eksperimen dan kelas kontrol hasil posttest kedua kelas sampel dilakukan dengan bantuan software SPSS.23.0 for windows. Kriteria yang digunakan adalah $H_{0}$ diterima jika nilai sig. (2tailed) $>$ taraf signifikan $(\alpha)$, sedangkan $H_{0}$ ditolak jika nilai sig. (2-tailed) < taraf signifikan $(\alpha)$.. Adapun hipotesis pengujian yang dilakukan sebagai berikut:

$\mathrm{H}_{0}$ : Tidak ada perbedaan yang signifikan antara hasil belajar matematika yang menggunakan model pembelajaran SAVI 
dengan pendekatan saintifik dan hasil belajar matematika yang menerima pendekatan saintifik.

$\mathrm{H}_{1}$ : Ada perbendaan yang signifikan antara hasil belajar matematika yang menggunakan model pembelajaran SAVI dengan pendekatan saintifik dan hasil belajar matematika yang menerima pendekatan saintifik.

Tabel 5 Hasil Uji-t

\begin{tabular}{|c|c|c|}
\hline Sig. (2-tailed) & Kriteria & Keterangan \\
\hline 0,000 & $\mathrm{H}_{0}$ ditolak & $\mathrm{H}_{1}$ diterima \\
\hline
\end{tabular}

Berdasarkan tabel 4.9 dapat dilihat bahwa nilai sig.(2-tailed) $=0,000<$ taraf signifikan $(\alpha=0,05)$. Jadi, dapat disimpulkan bahwa rata-rata hasil belajar matematika siswa yang memperoleh pembelajaran SAVI ada perbedaan yang signifikan dari pada peserta didik yang memperoleh pembelajaran saintifik.

Hasil penelitian yang dilakukan di SMPN 4 Kota Bengkulu kelas VIII pada materi statistika menunjukkan bahwa rata-rata hasil belajar siswa dikelas VIII 7 dengan menggunakan pembelajaran SAVI dengan pendekatan saintifik lebih dari pendekatan saintifik saja di kelas VIII SMP Negeri 4 Kota Bengkulu.

Analisis capaian hasil belajar dilakukan berdasarkan hasil nilai belajar peserta didik sesuai indikator tiap soal dengan kompetensi dasar menganalisis data berdasarkan ditribusi data. Berikut tabel indikator yang digunakan untuk mengukur hasil belajar peserta didik.

Tabel 5 Indikator Tes Hasil Belajar

\begin{tabular}{|c|l|}
\hline Indikator & \multicolumn{1}{|c|}{ Butir Soal } \\
\hline $\begin{array}{c}\text { Menentukan rata-rata (mean) } \\
\text { suatu data }\end{array}$ & $\begin{array}{l}\text { Soal nomor 1, 2 } \\
\text { dan 3 }\end{array}$ \\
\hline $\begin{array}{c}\text { Menentukan median suatu data } \\
\begin{array}{c}\text { Menentukan ukuran penyebaran } \\
\text { data }\end{array}\end{array}$ & $\begin{array}{l}\text { Soal nomor 4 } \\
\text { dan 5 }\end{array}$ \\
Soal nomor 6, \\
7 dan 8 \\
\hline
\end{tabular}

Hasil belajar peserta didik pada kedua kelas sampel didapati nilai rata-rata hasil belajar yang berbeda. Pada kelas eksperimen yang menggunakan model pembelajaran SAVI didapat nilai rata-rata 71,26 sedangkan pada kelas kontrol dengan pembelajaran saintifik nilai rata-rata 59,94. Dari kedua nilai rata-rata tersebut dapat dilihat bahwa nilai rata-rata pada kelas eksperimen lebih tinggi 11,32 poin dari pada nilai rata-rata pada kelas kontrol. Untuk nilai tertinggi, pada kelas eksperimen nilai tertinggi adalah 87 sedangkan pada kelas kontrol nilai tertinggi adalah 92. Nilai terendah untuk kelas eksperimen yakni 42 sedangkan pada kelas kontrol yakni 40 .

Indikator tentang menentukan rata-rata (mean) suatu data ditunjukkan pada soal nomor 1, 2 dan 3 kelas eksperimen dengan banyak peserta didik yang mengikuti ujian yaitu 35 dan yang berhasil menjawab soal nomor 1 dengan capaian skor maksimal sebesar 5,71\%, sedangkan kelas kontrol tidak ada yang menjawab benar dengan skor maksimal. Kesalahan yang terjadi pada kelas eksperimen dan kelas kontrol yaitu peserta didik banyak menjawab soal dengana langsung tanpa menguraikan terlebih dahulu. Sehingga berdampak berkurangnya poin penilaian yang mereka dapat. Sedangkan soal nomor 2 kelas eksperimen maupun kelas kontrol menunjukkan ada satu peserta didik yang bisa mencapai skor maksimal yang ditentukan. Untuk soal nomor 3 baik kelas eksperimen maupun kelas kontrol tidak ada satupun peserta didik yang menjawab benar dengan skor masksimal yang ditentukan.

Kesalahan yang dialami peserta didik pada dua kelas eksperimen secara keseluruhan hampir mirip, yaitu pada kurangnya beberapa bagian jawaban sehingga tidak mendapatkan nilai maksimal.

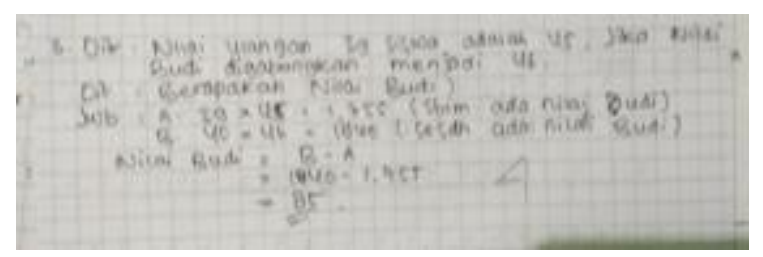

Gambar 1

Indikator tentang menentukan rata-rata (mean) suatu data, pada kelas eksperimen 
adanya pengaruh diberikannya model pembelajaran SAVI. Peserta didik lebih teliti dalam menjawab soal posttest yang diberikan.

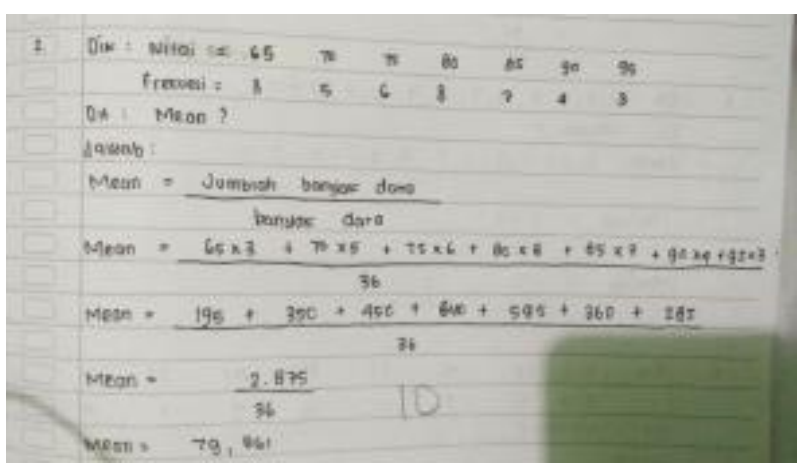

Gambar 2

Sedangkan pada kelas kontrol mereka lebih banyak menjawab soal dengan singkat tanpa menguraikan terlebih dahulu jawaban yang mereka dapat.

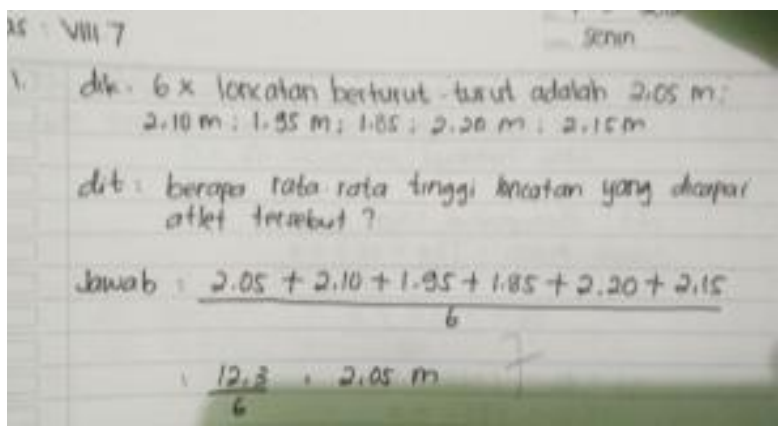

Gambar 3

Indikator tentang menentukan median suatu data ditunjukkan pada soal nomor 4 dan 5. Pada kelas eksperimen untuk soal nomor 4 berhasil menjawab capaian skor maksimal dengan total $8,57 \%$, sedangkan kelas kontrol berhasil menjawab soal nomor 4 sebesar $2,77 \%$ untuk capaian skor maksimal. Soal nomor 4 banyak peserta didik menjawab soal tanpa menggunakan rumus yang sudah diajarkan, mereka lebih mengurutkan data dan banyak membuang waktu. Untuk soal nomor 5 pada kelas kontrol peserta didik banyak menjawab soal median dengan mengurutkan datanya saja sehingga mengurangi poin penilainnya. Capaian skor maksimal pada kelas eksperimen sebesar $11,42 \%$ sedangkan pada kelas kontrol hanya $2,77 \%$. Perbedaan persentase capaian skor maksimal yang terjadi pada kedua kelas membuktikan adanya pengaruh model SAVI dalam pembelajaran. Terbukti pada soal nomor 5 di kelas kontrol, masih banyak peserta didik menjawab soal salah karena kurang teliti dalam pembagian dan cara membagi data dalam bentuk tabel juga kurang mengerti.

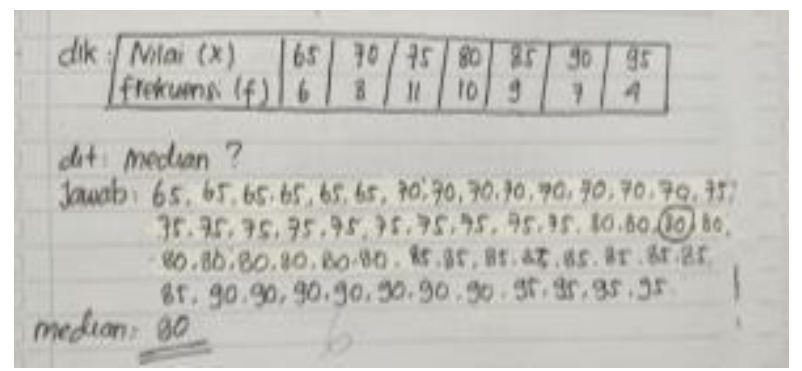

\section{Gambar 4}

Indikator tentang menentukan ukuran penyebaran data ditunjukkan pada soal nomor 6, 7, dan 8. Untuk soal nomor 6 kelas eskperimen dan kelas kontrol capaian skor maksimalnya sama dengan soal nomor 5 yaitu $11,42 \%$ kelas eksperimen dan 2,77\% kelas kontrol. Pada soal nomor 7 dengan capaian skor maksimal pada kelas eksperimen sebesar $8,57 \%$, sedangkan kelas kontrol tidak ada yang mencapai skor maksimal satupun. Persentase menunjukkan bahwa hasil belajar peserta didik kelas eksperimen lebih tinggi dari hasil belajar kelas kontrol dalam capaian skor maksimal pada soal nomor 7 . Untuk soal nomor 8 baik kelas eksperimen maupun kelas kontrol tidak ada satupun peserta didik yang mencapai skor masksimal yang sudah ditentukan oleh peneliti.

Dilihat dari hasil rata-rata kelas maupun banyak peserta didik yang berhasil menjawab soal dengan skor maksimal, kelas eksperimen memang memilliki angka yang lebih tinggi dibandingkan dengan kelas kontrol. Hal ini menunjukkan adanya perbedaan hasil belajar jika dilihat secara deskriptif langsung dan ternyata sesuai dengan apa yang didapat dari hasil uji hipotesis yang menyatakan bahwa terdapat perbedaan rata-rata hasil belajar antara kedua kelas sampel tersebut.

\section{PENUTUP}

\section{Kesimpulan}

Berdasarkan hasil penelitian diperoleh nilai rata-rata siswa kelas eksperimen $=71,26$ dan

Rafi, Della, Effie

Perbedaan Hasil Belajar Matematika Menggunakan Model Pembelajaran SAVI (Somatic, Auditory, Visual, Intellectuall) Dengan Pendekatan Saintifik Pada Siswa Kelas VIII SMP N 4 Kota Bengkulu 
siswa kelas kontrol $=59,94$. Dari hasil analisis data dengan pengujian hipotesis menggunakan uji-t diperoleh nilai $t_{\text {hitung }}=4,061$ dan nilai $t_{\text {tabel }}$ $=1,994$. Karena kriteria pengujian $t_{\text {hitung }}>t_{\text {tabel }}$ maka $\mathrm{H}_{0}$ ditolak. Jadi dapat disimpulkan bahwa rata-rata hasil belajar siswa dikelas VIII 7 dengan menggunakan pembelajaran SAVI dengan saintifik mempunyai perbedaan yang signifikan dari pembelajaran saintifik saja kelas VIII 6 pada materi statistika di SMP Negeri 4 Kota Bengkulu.

\section{Saran}

Berdasarkan hasil penelitian yang telah dilakukan, maka saran yang dapat diberikan adalah : (1) Penerapan model pembelajaran SAVI saat menggunakan LKPD, siswa harus diberikan LKPD per-individu bukan perkelompok karena jika diberikan perkelompok siswa yang tidak dapat LKPD akan malasmalasan. (2) LKPD yang digunakan sebaiknya dperhatikan lagi agar tidak terjadi kesalahan dalam penulisan yang akan mengakibatkan siswa kebingungan.

\section{DAFTAR PUSTAKA}

Arikunto, S. (1986). Prosedur Penelitian. Jakarta: Bina Aksara.

Arikunto, S. (2009). Dasar-dasar Evaluasi Pendidikan. Jakarta: Bumi Aksara.

Hosnan, M. (2014). Pendekatan Saintifik Dan Kontekstual Dalam Pembelajaran Abad 21. Bogor: Ghalia Indonesia.

Huda, M. (2017). Model-Model Pengajaran dan Pembelajaran. Yogyakarta: Pustaka Belajar.

Lestari, K. E., \& Yhudanegara, M. R. (2017). Penelitian Pendidikan Matematika. Bamdung: PT Refika Aditama.

Meier, D. (2004). The Accelerated Learning Handbook. Bandung: Kaifa.

Shoimin, A. (2014). 68 Model Pembelajaran Inovatif dalam kurikulum 2013. Yogyakarta: Ar-Ruzz Media.

Sugiyono. (2014). Metode Penelitian Pendidikan (Pendekatan Kuantitatif,
Kualitatif, dan $R \& D)$. Bandung: Alfabeta.

Sugiyono. (2016). Metode Penelitian Kuantitatif, Kualitatif, dan Kombinasi (Mixed Methods). Bandung: Alfabeta.

Sani, R. A. (2014). Pembelajaran Saintifik untuk Implementasi Kurikulum 2013. Jakarta: Bumi Aksara. 